удК $551.733 .11(474.2)$

D. KALJO, Viive VIIRA

\title{
CO-OCCURRENCES OF CONODONTS AND GRAPTOLITES IN THE ESTONIAN EARLY TREMADOC
}

The Cambrian-Ordovician Boundary Working Group has agreed to define the boundary by conodonts and to place the actual level below the appearance of the first nematophorous graptolites. Recent publications (Geol. Mag., 1988, 125, N 4) show that in several sections, including Dayangcha, China and Naersnes, Norway, the level of graptolite appearance falls into Cordylodus lindstromi Zone. Only the East Baltic data are different as are the data from the Newfoundland sections, but the latter are doubtful (compare the papers by Erdtmann (1988) and Barnes (1988) in Geol. Mag. mentioned). We accept that here on the occasion of both consensus and differences the concept of $C$. lindstrom $i$ has been of consequence. In this paper we shall only present the data obtained in the North-Estonian sections.

To the Estonian early Tremadoc are related the essential mineral resources of our republic - Obolus phosphorite and Dictyonema shale. In the course of their investigation an abundant borehole material has been obtained which can be applied to the study of different problems. Space fimitations of this communication do not allow us to present all the sections studied and we shall give only a few examples characteristic of certain areas in North Estonia. The location of the borehole sections to be discussed below is shown in a sketch map (Fig. 1) and their faunal logs in Fig. 2.

Starting from the west we shall give some comments.

Borehole D-10. Dictyonema Shale (= Türisalu Formation, $7 \mathrm{~m}$ thick, here we retain the traditional name as the rockname) lies between two large hiatuses (underlying is Tiskre Formation and overlying is Volkhov Stage). Its upper part abounds in graptolites, especially in splendid specimens of Rhabdinopora flabelliformis norvegica. Among the first graptolites there occurs $R$. $f$. cf. socialis and the last $R$. flabelliformis was presented by a flabelliformis/anglica transient. Conodont data show that the whole assemblage belongs to the Cordylodus rotundatus-C. angulatus Zone.

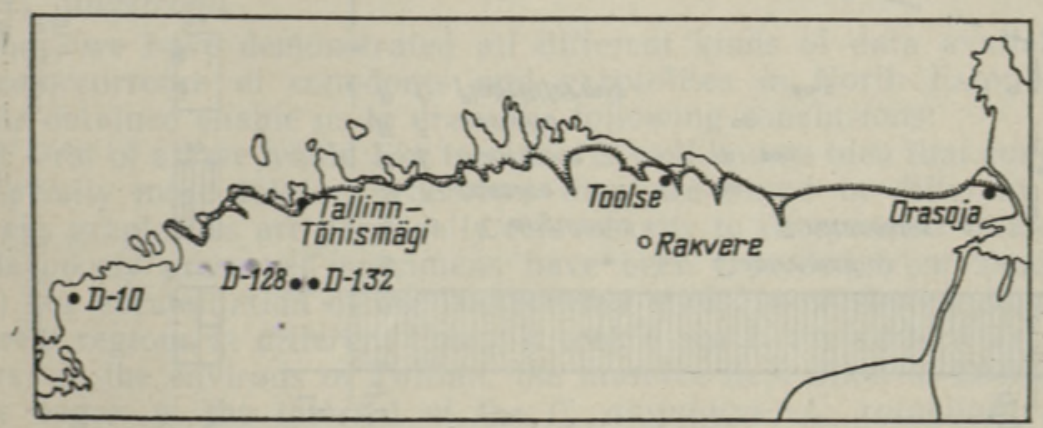

Fig. 1. Sketch map showing location of the sections discussed in this study.

C) Eesti TA Toimetised. Geoloogia, 1989 


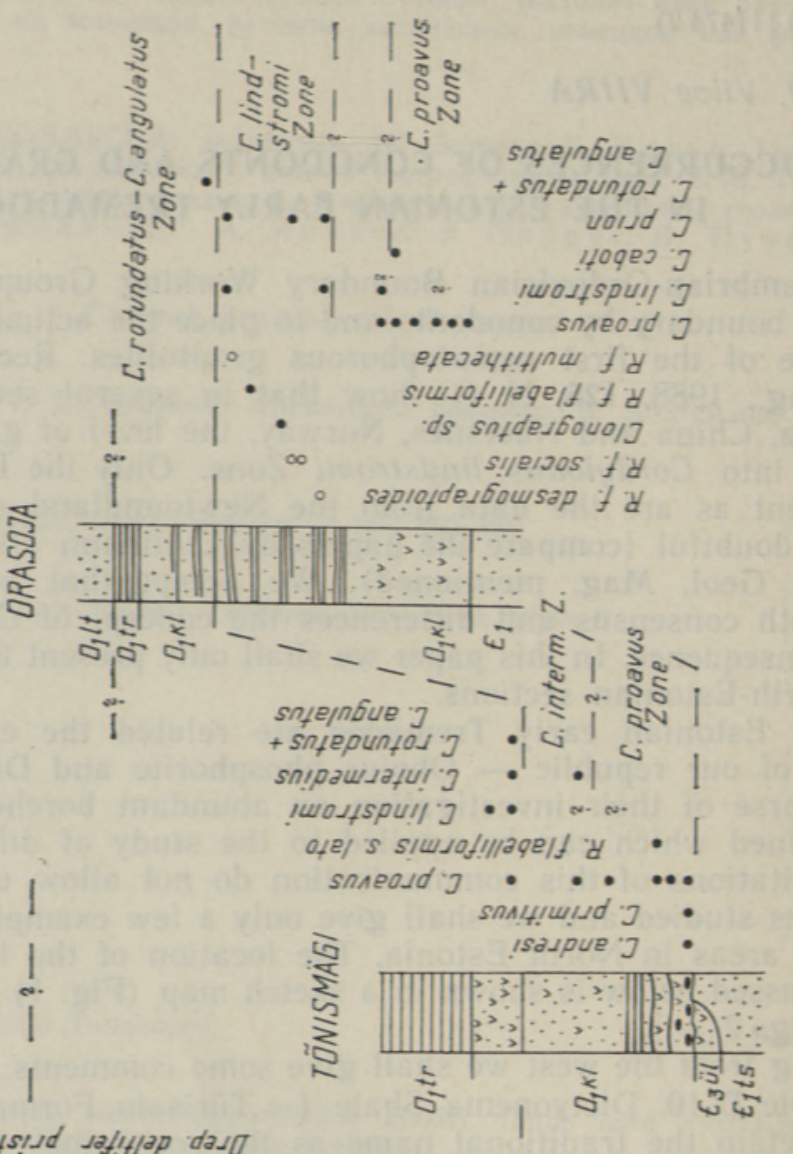

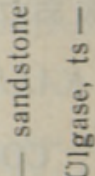

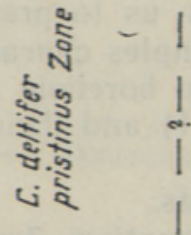

- snuifsisd jajiflap dasd lie ta ds snpolfipjoj •

snyepnbue J + snyepunpos

efejaytitynum ja $\mathrm{f}$ a d

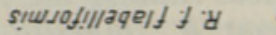

$\stackrel{\infty}{7}$
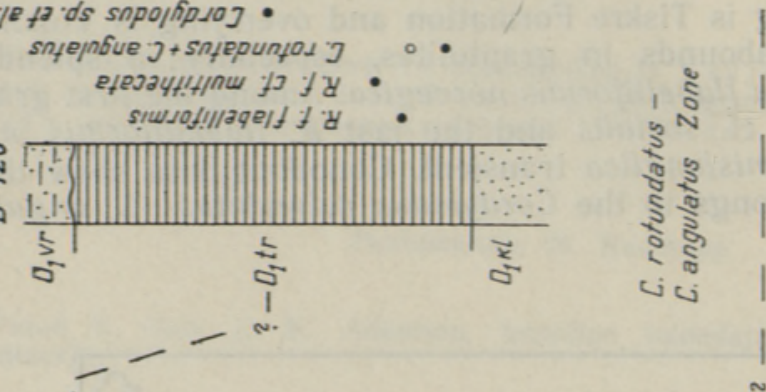

递冚

응으

केष्य

흘

당



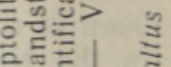

政

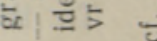

$\div \div 1=$

क क क ज

or

근

드잉

औ气 1 के

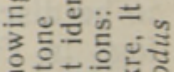



क ज्ञ

色 100

$\cos _{\infty} 0$ e

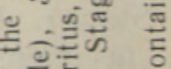

L:

的

음ำ응





는흘

งิย?

bis 3

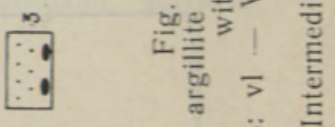

i 1100

siunofinlagelf if d |

sifeloos if id



- sntepuntarja snjeinbieja.

sก!pausafu! :
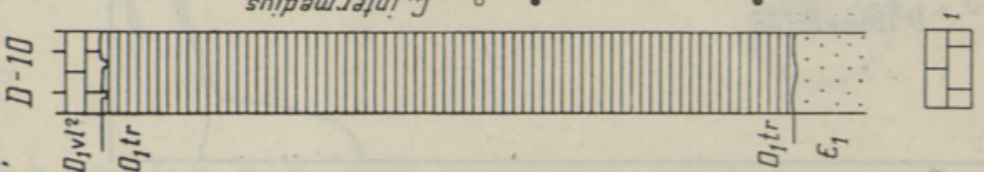

$1 \ddot{\ddot{e}}=$

$\sim \stackrel{\frac{\partial}{E}}{\underline{5}}$

= 
Borehole D-128. Dictyonema Shale (4 $\mathrm{m}$ thick) lies between the Varangu and the Kallavere Formations. In the lower part of the Shale there occurs among the others $R$. $f$. cf. multithecata characteristic of the top of $R$. flabelliformis Zone. Below these graptolites there were found conodonts of the $C$. rotundatus $-C$. angulatus Zone. The upper part of the Shale is characterized by Drepanoistodus deltifer pristinus, the intermediate assemblage (Cordylodus sp. etc.) cannot be interpreted unambiguously.

It should be mentioned that ten kilometers to the east, in the borehole D-132 (Fig. 1) in the Dictyonema Shale Kiaerograptus sp., a member of upper Tremadoc assemblage, is found only $75 \mathrm{~cm}$ higher than $R$. flabelliformis aff. multithecata. Unfortunately, conodonts have not been studied in this borehole so far. However, the correlation of the near-lying borehole sections is reliable enough.

The Rhabdinopora flabelliformis group occurred in the abovementioned West-Estonian boreholes together with relatively high conodont assemblage, belonging to the $C$. rotundatus $-C$. angulatus Zone, which lies at the boundary of the early and late Tremadoc. We can also see that the graptolites are often represented by the higher-occurring subspecies multithecata, anglica etc.

In the sections located in Tailinn and east of it, the picture is more complicated and it is of importance that the graptolites have been found in the intercalations of the Dictyonema Shale in the lower part of the Kallavere Formation.

Tõnismägi section (Figs 1,2) from an excavation made for a new building of the National Library. The $R$. flabeiliformis group, including cf. sociale together with $C$. proavus etc., has been found above the Obolus conglomerate. This has enabled us to interpret this level as the upper part of the $C$. proavus Zone (see Kaljo et al., 1988).

The Mäekalda section (eastern part of Tallinn) offers almost the same picture. The Rhabdinopora flabelliformis group appears in one the first shale intercalations - a bit higher of the last $C$. andresi specimens and occurs together with the first elements of $C$. intermedius. Unlike the Tōnismägi section the $C$. lindstromi Zone is well-developed in the upper part.

In the Toolse section (Fig. 1, described by Kaljo et al., 1986) attention should be paid to the circumstance that the Rhabdinopora flabelliformis group, represented here by aff. multithecata, occurs together with $C$. lindstromi in the Kallavere Formation, just higher the $C$. angulatus $-C$. rotundatus assemblage makes its appearance and in the Türisalu Formation there appear Clonograptus and \&Didymograptus» together with the wellknown Drepanoistodus deltifer pristinus Zone assemblage.

Analogical picture is observed in the sections up to the Syass River (Kaljo et al., 1986), it is especially prominent in the Orasoja outcrop (Fig. 2) where the rather diverse graptolite assemblage occurs together with $C$. lindstromi.

Thus, we have demonstrated all different kinds of data available on the co-occurrence of conodonts and graptolites in North Estonia. The results obtained enable us to draw the following conclusions:

1) first of all we would like to repeat a well-known idea that conodonts are facially more tolerant, therefore they are found in different rocks, whereas graptolites are practically related only to Dictyonema Shale; only single poorly preserved specimens have been recorded from sandstone;

2) the accumulation of the Dictyonema muds (now shales) started in different regions at different times; it took place at the earliest (as interlayers) in the environs of Tallinn, the massive deposition of Dictyonema muds began at the interval of the $C$. angulatus $-C$. rotundatus Zone, however, even then diachronously, and we can see now that the age of the bottom of the Dictyonema Shale became younger from the west to the east; 
3) the Rhabdinopora flabelliformis group makes its first appearance also at different levels. In the vicinity of Tallinn it took place in the top of the $C$. proavus Zone or in the $C$. intermedius Zone, to the east of Tallinn it is fixed at the level of the $C$. lindstromi Zone, and to the west at the level of the $C$. angulatus $-C$. rotundatus Zone. We have to think about the paleogeographical sense of this diachroneity, especially when we consider that from the lower half of the Shale in the borehole D-10 and in some other boreholes we have not found any graptolites until now;

4) the material obtained from the East Baltic shows that the cooccurrence of conodonts and graptolites differs considerably from area to area due to facies conditions and for some unknown reasons (D-10). Therefore, while defining the Cambrian-Ordovician boundary, we have to look for a level which may be easily defined by some fossils, say conodonts, as decided by the working group, and not to link it closely with the level where nematophorous graptolites made their first appearance.

At least in North Estonia the distribution of the R. flabelliformis group is not easy to interpret unequivocally for that purpose.

\section{REFERENCES}

Barnes, $C$. R. The proposed Cambrian-Ordovician global boundary stratotype and point (GSSP) in western Newfoundland, Canada // Geol. Mag., -1988, 125, N 4, $381-414$.

Erdtmann, B. D. The earliest Ordovician nematophorid graptolites: taxonomy and correlation // Geol. Mag., 1988, 125, N 4, 327-348.

$\checkmark$ Kaljo, D., Borovko, N., Heinsalu, H., Khazanovich, K., Mens, K., Popov, L., Sergeyeva, S., Sobolevskaya, R., Viira, V. The Cambrian-Ordovician boundary in the Baltic-Ladoga clint area (North Estonia and Leningrad Region, USSR) // Proc. Acad. Sci. ESSR. Geol., 1986, 35, N 3, 97-108.

$\checkmark$ Kaljo, D., Heinsalu, H., Mens, K., Puura, I., Viira, V. Cambrian-Ordovician boundary beds at Tönismägi, Tallinn, North Estonia // Geol. Mag., 1988, 125, N 4, 457463 .

Academy of Sciences of the Estonian SSR, Institute of Geology

Received Jan. 18, 1989

D. KALJO, Viive VIIRA

\section{KONODONTIDE JA GRAPTOLIITIDE KOOSESINEMISEST EESTI VARA-TREMADOCIS}

Tallinna piirkonnas on esimesed graptoliidid leitud koos Cordylodus proavus'e ja $C$. intermedius'ega, sellest alast ida pool koos $C$. lindstromi'ga ja läâne pool $C$. rotundatus'e ja $C$. angulatus'ega.

\section{Д. КАЛЬО, Вийве ВИИРА}

\section{СОВМЕСТНОЕ РАСПРОСТРАНЕНИЕ КОНОДОНТОВ И ГРАПТОЛИТОВ В РАННЕМ ТРЕМАДОКЕ ЭСТОНИИ}

В районе Таллинна самые ранние граптолиты найдены совместно с конодонтами Cordylodus proavus и $C$. intermedius, восточнее города - с $C$. lindstromi, а западнее с C. rotundatus н $C$. angulatus. 